\title{
PERANCANGAN BUKU POP-UP ALAT TRANSPORTASI TRADISIONAL PALEMBANG
}

\author{
Fatimatuzzahrah $^{1)}$, Mukhsin Patriansyah $^{2)}$, Aryanto $^{3)}$ \\ 1),2),3) Program Studi Desain Komunikasi Visual Universitas Indo Global Mandiri \\ Jl Jend. Sudirman No. 629 KM. 4 Palembang Kode Pos 30129 \\ Email : zahrasyahab2@gmail.com ${ }^{1)}, \underline{\text { mukhsin.patriansyah8@gmail.com }}^{2)}$, aryantoajal@gmail.com $^{3}$ )
}

\begin{abstract}
Traditional transportation of Palembang is now being replaced by modern transportation so the traditional transportation of Palembang has been forgotten by people. As the successor generation, we have to keep the traditions and the local cultures by still using traditional transportation which is currently still to be found. But in fact, some people have started to forget the traditional transportation, and haven't introduced the traditional transportation to their children. Therefore, it was designed an appropriate educational media for early childhood, that is a pop-up book that can stimulate the curiosity of the children and also train the child's imagination. Pop-up book themed traditional transportation of Palembang is as an educational media for the children by introducing traditional transportation of Palembang and is as one of the effort to preserve the tradition of using traditional transportation of Palembang.
\end{abstract}

Keywords : Traditional Transportation of Palembang, Educational Media, Pop-up Book.

\section{Pendahuluan}

Buku sangatlah penting untuk memajukan bangsa. Dengan membaca buku dapat meningkatkan kecerdasan, kreatifitas dan tanggap akan keadaan sekitar. Oleh karena itu buku harus diperkenalkan kepada anak-anak sejak usai dini. Usia yang sangat efektif untuk memperkenalkan buku kepada anak-anak adalah sejak usia 3-5 tahun yang merupakan masa-masa penting bagi anak. Perkembangan anak pada masa-masa penting ini harus dioptimalkan, sehingga dibutuhkan simulasi edukasi yang tepat, dan salah satu simulasi yang tepat untuk anak usia 3-5 tahun adalah dengan mebacakan buku cerita ataupun buku bergambar. Membacakan buku cerita kepada anak-anak usia 3- 5 tahun merupakan salah satu cara yang efektif untuk mengembangkan aspek-aspek kognitif (pengetahuan), afektif (perasaan), sosial, imajinasi dan aspek konatif (penghayatan) anak-anak [1]. Membacakan sebuha buku memerlukan sebuah media edukasi yang tepat. Media edukasi yang sesuai dengan anak usia 3-5 tahun adalah buku pop-up, karena buku pop-up dapat merangsang keingintahuan anak dan juga melatih daya imajinasinya, selain itu buku pop-up memberikan visulisasi cerita yang lebih hidup. Imajinasi lebih penting dibandingkan dengan pengetahuan karena pengetahuan terbatas, sedangkan imajinasi merengkuh seluruh dunia [2].

Buku pop-up untuk anak-anak yang berada dipasaran didominasi oleh cerita-cerita imaginative seperti Disney, dan cerita alat transportasi modern. Hal ini menyebabkan banyak anak-anak yang kurang mengenal alat-alat trasnportasi tradisional. Palembang merupakan salah satu kota yang memiliki alat trasnportasi tradisional yang khas, yaitu perahu "ketek" dan becak, selain itu di Kota Palembang juga terdapat alat transportasi tradisional seperti delman dan sepeda onthel, meskipun delman dan sepeda onthel bukan asli dari Palembang. Alat trasnportasi tradisional di Kota Palembang saat ini sudah mulai dilupakan oleh pemrtintah dan masyarakat dan sudah banyak yang sudah dimodifikasi. Oleh karena itu untuk dalam upaya tetap mempertahankan dan meningkatkan nilai tradisio dan budaya lokal yang saat ini sudah mulai terlupakan, maka penulis akan perancang buku рор-ир sebagai media edukasi dengan memilih alat transportasi tradisional Palembang sebagai ide perancangan. Perancangan buku pop-up ini tidak hanya memberikan ilmu pengetahuan dan stimulasi untuk perkembangan otak anak, tetapi sebagai upaya untuk memperkenalkan alat transportasi tradisional di Kota Palembang, serta memerkenalkan nilai budaya lokal kepada orang tua dan anak.

Pada perancangan buku pop-up alat transportasi tradisional Palembang dilakukannya metode perancangan, metode yang dilakukan adalah metode pengumpulan data. Metode pengumpulan data merupakan langkah yang paling strategis dalam penelitian, karena tujuan utama dari penelitian adalah pengumpulan data [3]. Tahap metode perancangan mulai melakukan pengumpulan data yang diperlukan dalam penelitian melalui proses riset data dari buku, media internet, jurnal, survey dan melakukan wawancara, salah satunya berupa permasalahan yang terjadi, seperti kurangnya media edukasi yang menarik untuk anak-anak usia 3- 5 tahun. Setelah pengumpulan data-data akan melanjutkan strategi perancangan serta mengumpulkan beberapa referensi perancangan buku рор-up alat transportasi tradisional Palembang.

Adapun pada perancangan buku pop-up alat transportasi tradisional Palembang akan menjabarkan beberapa landasan teori yang digunakan, diantaranya:

\section{Teori Semiotika}

Teori semiotika Charles Sanders Pierce dengan sistem kategorinya sangat tepat digunakan dalam melahirkan karya ini. Menurut Pierce, mendefinisikan "Tanda berpartisipasi dalam tiga macam kategori: representamen, 
objek dan interpretan" [4]. Tanda adalah sesuatu yang berbentuk fisik sehingga dapat ditangkap oleh panca indera. Tanda menurut Pierce terhadap unsur kenyataan tanda, terdapat konsep berupa ikon (tanda yang muncul dari perwakilan fisik atau kemiripan), indeks (tanda yang muncul dari hubungan sebab akibat) dan simbol (tanda yang muncul dari sebuah kesepakatan atau konvensi).

Ikon pada perancangan buku pop-up alat transportasi tradisional Palembang adalah becak dan perahu ketek/getek yang merupakan objek utama, delman, dan sepeda onthel sebagai objek pendukung serta keseluruhan tampilan visual yang disajikan dari warna dan background (latar belakang) dalam media. Penggunaan indeks pada perancangan buku pop-up alat transportasi tradisional Palembang yaitu keberadaan alat transportasi tradisional seperti becak, perahu ketek/getek, delman, dan sepeda onthel yang sudah mulai dilupakan karena keberadaan alat transportasi modern. Penggunaan simbol pada perancangan buku pop-up alat transportasi tradisional Palembang, berupa kontradiksi yang terjadi antara alat transportasi modern yang saat ini sudah mendominasi dan alat transportasi tradisional sudah mulai dilupakan karena pengaruh dari perkembangan teknologi. Pernyataan tersebut sudah menjadi konvensi atau kesepakatan yang terjadi khususnya di Kota Palembang.

\section{Estetika}

yaitu teori yang dikemukakan oleh Djelantik yang memaparkan tiga nilai estetis yang membuat baik dan indah, yaitu Wujud atau rupa (Appearance), Bobot atau Isi (Content, subtance) dan Penampilan, Penyajian (Presentation). Adapun wujud atau rupa pada perancangan buku pop-up alat tranportasi tradisional Palembang menggunakan garis yang tebal dan tegas, serta menggunakan warna-warna yang disesuaikan dengan anak-anak usia 3- 5 tahun seperti komposisi warna pokok yang terdiri dari merah, kuning, hijau, dan biru serta warna netral seperti hitam, putih dan coklat serta tidak menggunakan gradasi warna. Penggunaan visual lebih mendominasi dibandingkan dengan teks bacaannya.

Bobot atau isi dalam perancangan buku pop-up alat transportasi tradisional ini, yaitu adanya kontradiksi yang terjadi antara alat transportasi modern yang saat ini sudah mendominasi dan alat transportasi tradisional sudah mulai dilupakan karena pengaruh dari perkembangan teknologi. Penampilan atau penyajian pada perancangan buku popup alat transportasi tradisional Palembang dengan menampilkan konsep pop-up $180^{\circ}$, dikarenakan pop-up $180^{\circ}$ lebih menarik serta lebih memudahkan anak-anak usia 3- 5 tahun mengenal bentuk sehingga membuat anakanak dan orang tua yang membaca buku pop-up akan lebih antusias. Penampilan pada saat melakukan sebuah pameran dengan menampilkan buku pop-up $180^{\circ}$ yang merupakan media utama dan ditambah dengan media pendukung seperti poster, stiker, dan banner yang merupakan media promosi.

\section{Teori Desain Komunikasi Visual}

Desain Komunikasi Visual adalah suatu disiplin ilmu yang bertujuan mempelajari konsep-konsep komunikasi serta ungkapan kreatif melalui berbagai media untuk menyampaikan pesan dan gagasan secara visual dengan mengelola elemen-elemen grafis yang berupa bentuk dan gambar, tatanan huruf, serta komposisi warna serta layout, dengan demikian, gagasan bisa diterima oleh orang atau kelompok yang menjadi penerima pesan [5].

Pada perancangan buku pop-up alat transportasi tradisional haruslah memiliki prinsip-prinsip dalam merancang agar dapat memiliki nilai estetik dengan diperhatikannya komposisi. Komposisi dapat dilihat dari beberapa hal berdasarkan prinsip-prinsip berupa Kesatuan (unity), Keseimbangan (Balance), Irama (Rhythm) dan Tekanan (emphasis). Adapun kesatuan (unity) pada perancangan buku pop-up dengan menggunakan tema alat transportasi tradisional, serta penggunaan warna pokok yang terdiri dari merah, kuning, hijau, dan biru serta warna netral seperti hitam, putih dan coklat, dengan menggunakan ilustrasi pemandangan perkotaan dan pedesaan. Keseimbangan (Balance) pada perancangan buku pop-up menggunakan keseimbangan asimetrs, penggunaan warna dan bentuk yang seimbang. Irama (Rhythm) pada perancangan buku pop-up ala transportasi tradsional, yaitu menggunakan alat transportasi dengan bentuk yang sama pada setiap halaman, serta pengulangan karakter yang ada pada setiap halaman agar dapat terciptanya sebuah ritme. Unsur yang terakhir adalah tekanan (emphasis) pada erancangan buku pop-up alat transportasi tradisional yaitu dengan menggunakan visual рор-up yang akan menjadi titik perhatian dari pembaca.

\section{Teori Warna}

Perancang buku pop-up alat transportasi menggunakan teori yang dikemukakan oleh Albert Munsell pada tahun 1858. Teori Munsell menyatakan bahwa warna pokok terdiri dari merah, kuning, hijau, biru dan jingga. Sementara warna sekunder terdiri dari warna jingga, hijau muda, hijau tua, biru tua dan nila [5]. Pada perancangan buku pop-up menggunakan sistem warna sebagai warna representasi dari alam. Penggunaan warna representasi alam pada perancangan ini, yaitu dengan menggunakan warna-warna yang kuat dan kontras dengan penggabungan antara warna panas dan warna dingin, sehingga memberikan kesan ceria yang sesuai dengan psikologi anak-anak usia 3- 5 tahun.

\section{Buku Pop-Up}

Pop-up adalah salah satu bidang kreatif paper engineering yang di Indonesia kini semakin digemari dan sedang berkembang. Pop-up merupakan istilah yang sering diterapkan pada setiap buku tiga dimensi maupun bergerak. Pada perancangan buku pop-up alat transportasi tradisional Palembang ini menggunakan tampilan Pop-up $180^{\circ}$ dan visual kartun dengan penggunaan warna-warna yang cerah.

\section{Psikologi Anak}

Pada usia 1 sampai 5 tahun perkembangan bahasa meningkat, anak-anak usia 3- 5 tahun mulai menyebutkan nama-nama benda yang dilihatnya. Jenis buku yang tepat untuk stimulasi pada perkembangan anak-anak usia 3-5 
tahun adalah buku pop-up. Buku pop-up memberikan visualisasi yang mendominasi dibandingkan ceritanya, hal ini sesuai dengan psikologi anak mengenai kecerdasan visualisasi di usia 3 sampai 5 tahun. Memberikan anak berbagai macam gambar dan minta anak untuk menjelaskan kembali gambar yang baru dilihat, bila anak keliru mengiterpresentasikan gambar, perlihatkan kembali gambar tersebut dan minta anak melihat lebih detail. Hal ini dapat melatih kecerdasan visualisasinya, karena dengan memperkenalkan gambar pada anak di usia 1 sampai 5 tahun akan melatih otak anak dan akan semakin terlatih mengenali suatu objek secara detail [6].

\section{Pembahasan}

Analisa data pada perancangan buku pop-up alat transportasi tradsional Palembang, menggunakan metode analisa SWOT yang merupakan kumpulan data dari hasil identifikasi data, data analisa pemasaran, wawancara dan observasi di TKIT Ulil Albab Palembang, Yaitu:

\section{a. Stregth}

Buku Pop-up:

1. Sebagai simulasi yang efektif untuk perkembangan otak anak-anak.

2. Didominasi dengan visualisasi yang membuat anak lebih tertarik dan antusias.

\section{Transportasi Tradisional:}

1. Melestarikan budaya lokal

2. Mengenalkan alat transportasi tradisional kepada generasi selanjutnya.

\section{Anak 3-5 tahun:}

1. Dapat menanamkan kecintaan pada buku.

2. Menambah ilmu pengetahuan dan melatih imajinasinya dan merangsang keingintahuannya.

\section{b. Weakness}

Buku Pop-up:

1. Pembuatan buku pop-up cukup rumit, sehingga memakan banyak waktu dan harus lebih teliti.

2. Harganya yang cukup tinggi.

\section{Transportasi Tradisional:}

1. Sudah mulai dilupakan dan kurangnya perhatian dari masyarakat.

\section{Anak 3-5 tahun:}

1. Kurangnya minat baca

2. Kurangnya melakukan kegiatan mendongeng

\section{c. Oppurtunity}

Buku Pop-up:

1. Buku pop-up masih jarag di Indonesia

2. Banyaknya Buku pop-up import

Transportasi Tradisional:

1. Upaya melestarsikan nilai budaya dan tradisi lokal

\section{Anak 3-5 tahun:}

Usia yang tepat untuk memperkenalkan buku, menanamkan kecintaan pada buku dengan tema alat transportasi tradisional.

\section{d. Therat}

\section{Buku Pop-up:}

1. Anak-anak sudah diperkenalkan dengan media elektronik seperti Televisi dan video animasi.

\section{Transportasi Tradisional:}

1. Banyak yang dimodifikasi sehingga alat transportasi tradisional mulai hilang.

\section{Anak 3-5 tahun:}

1. Mudah kecanduan media elektronik.

\section{Strategi Strenght dan Opportunity:}

Menjadikan buku pop-up sebagai media eukasi untuk anak-anak agar menambah ilmu pengetahuan dengan memperkenalkan alat transportasi tradisional dan menanamkan kecintaan anak-anak pada buku.

\section{Strategi Weakness dan Opportunity:}

Pembuatan yang rumit sehingga buku pop-up masih jarang, maka dengan perancangan buku pop-up ini akan menambah koleksi buku untuk anak-anak dengan tema alat transportasi tradisional sebagai upaya pelestarsian alat transportasi tradisional yang sudah mulai dilupakan masyarakat.

\section{Strategi Streght dan Threat:}

1. Membuat media edukasi yang menarik, sehingga anakanak tertarik sehingga tidak kecanduan terhadap media-media elektronik yang belum saatnya mereka gunakan.

2. Memperkenalkan alat trasnportasi tradisional yang sudah ada sejak dulu hingga saat ini.

\section{Strategi Weakness dan Threat:}

1. Membuat buku pop-up dengan cerita dan visual yang menarik, dengan mengangakat tema alat transportasi tradisional sebagai upaya pelestarian nilai budaya lokal, sehingga anak-anak akan lebih menyukai buku pop-up dibandingkan dengan media elektronik.

Kesimpulan analisis data pada perancangan buku popup alat transportasi tradisional Palembang Buku pop-up alat transportasi tradisional ini dapat dijadikan sebagai simulasi yang efektif untuk perkembangan otak anak. Buku yang didominasi oleh visual ini dapat membuat anak-anak tertarik sehingga akan tumbuh kecintaan anak terhadap buku yang dapat menambahkan ilmu pengetahuan anak. Mengangkat tema alat transportasi tradisional Palembang, anak akan diperkenalkan dengan alat transportasi tradisional Palembang yang merupakan upaya melestarikan nilai budaya dan tradisi lokal.

Pembuatan buku pop-up ini cukup rumit jika tidak menggunakan bahan-bahan yang berkualitas buku akan mudah rusak, jadi diperlukan bahan-bahan yang berkualitas dan tidak mudah rusak, sehingga harga jualnya cukup tinggi. Oleh karena itu buku pop-up ini 
hanya dapat dijangkau oleh masyarakat menengah ke atas.

Perancangan buku pop-up alat transportasi tradisional Palembang membutuhkan media-media utama dan pendukung yang dapat meningkaykan promosi buku popup alat trasnortasi tradisional Palembang. Media utama pada perancangan buku pop-up alat transportasi tradisional Palembang adalah buku pop-upi $180^{\circ}$, pemilihan buku pop-up karena di pasaran buku pop-up lokal dipasaran masih jarang, hal ini dapat menajdi peluangb besar untuk merancang buku pop-up dengan mengangkat tema lokal. Selain itu buku pop-up dapat di jadikan media edukasi untuk anak.Media pendukung pada perancangan buku pop-up alat transportasi tradisional Palembang, yaitu Poster, X-Banner, Stiker, Gantungan kuci, Pin, kaos dan rak buku. Untuk program media pada perancangan buku pop-up alat transportasi tradisional Palembang, yaitu:

Tabel 1 Tabel program media

\begin{tabular}{|c|c|c|c|c|c|}
\hline $\mathrm{x}$ & Sledia & Balitas & Laticasi & Msarecen & Durase \\
\hline 1 & Bchupsow & $\begin{array}{l}100 \\
\text { hrah }\end{array}$ & 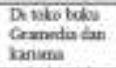 & 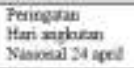 & Itralm \\
\hline 2 & Power & $\begin{array}{l}50 \\
\text { teuh }\end{array}$ & 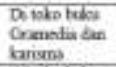 & 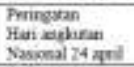 & Itriln \\
\hline 3 & X-Thenph & Bual. & $\begin{array}{l}\text { Dr tobs bobs } \\
\text { Oratinda dan } \\
\text { kanims }\end{array}$ & 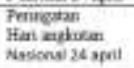 & thuan \\
\hline 4 & Stàn & $\begin{array}{l}100 \\
\text { hath }\end{array}$ & 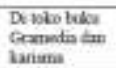 & 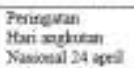 & 1 bulat \\
\hline 5 & $\begin{array}{l}\text { Cand unein } \\
\text { kasci Dent pen }\end{array}$ & $\begin{array}{l}300 \\
\text { tuch }\end{array}$ & 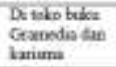 & 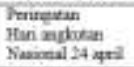 & t basta \\
\hline 0 & Kan & 12 & 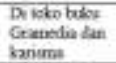 & 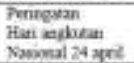 & 1 Gallet \\
\hline 7 & 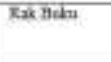 & teak & 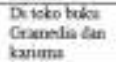 & 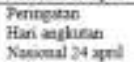 & I Gilat \\
\hline
\end{tabular}

Pada perencanaan kreatif pada buku pop-up ini mengangkat tema alat trasnportasi tradisional Palembang, yang ditujukan kepada anak-anak usia 3-5 tahun yang dapat dijadikan simulasi yang efektif untuk perkembangan otak anak. Mengangkat tema alat transportasi tradisioanl Palembang dapat membuat anak usia 3-5 tahun mengenal alat transpotasi tradisional yang berda disekitar mereka, selain itu dapat menumbuhkan kecintaan anak terhadap buku, dapat bersosialisasi dan mengeratkan kedekatan anak dan orang tua dengan cara mendongengkan sebuah cerita. Penggunaan cerita pada bbuku рор-ир alat transportasi tradisional ini dapat melatih daya imajinasinya serta menambahkan ilmu pengetahuan dengan menyebutkan nama-nama alat transportasi tradisional, mengenal bentuk dan warna yang terdapat dalam buku.

Pada perancangan buku pop-up alat trasnportasi dibutuhkannya sebuah aplikasi perancangan guna untuk menentukan menentukan proses pembuatan buku seperti judul buku, dan media pendukung lainnya. Aplikasi Perancangan yang dilakukan pada perancangan buku popup alat transportasi tradisional Palembang meliputi :

\section{Judul Buku}

Judul buku yang digunakan pada perancangan ini adalah "Aku Tahu" dan "Perjalanan Lila dan Lilo". Kedua
Headline ini akan menggunakan warna cerah dan ceria yang mecirikhaskan anaanak. Penggunaan objek visual yaitu becak dan "ketek" yang merupakan ciri dari sebuah kendaraan khas Palembang.

\section{Buku pop-up}

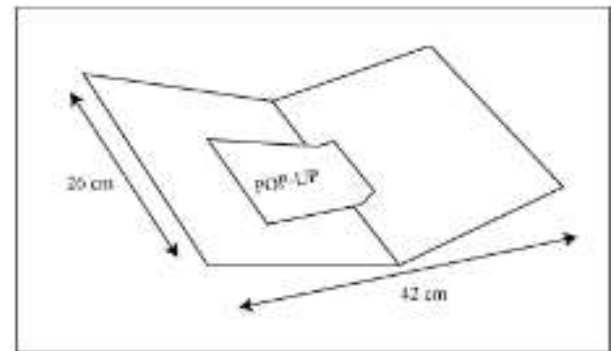

Gambar 1. Ukuran dan bentuk Buku pop-up

Pada perancangan buku pop-up alat transportasi tradisional Palembang, pop-up akan menjadi tampilan utama yang akan digunakan pada setiap halamannya dengan tehnik yang berbeda. Buku pop-up alat transportasi tradisional ini berbentuk persegi dengan ukuran sampul $21,5 \mathrm{~cm}$ × $27 \mathrm{~cm}$ dengan ukuran setiap halamannya $42 \mathrm{~cm} \times 26 \mathrm{~cm}$. Pada halaman buku pop-up alat transportasi tradisional Palembang akan dirancang menyerupai pemandangan di kota palembang seperti pemandangan sungai musi. Alat transportasi menjadi objek yang akan di pop-up kan dan pada salah satu sudut buku akan terdapat teks cerita. Buku pop-up akan dibuat dengan bahan art paper 310 gr, menggunakan bahan yang keras dan tebal dikarenakan agar buku pop-up ini tidak mudah rusak.

\section{Alat Transportasi Tradisional}

Alat transportasi tradisional pada buku pop-up akan menjadi tema utama dimana setiap halaman akan menjelaskan alat transportasi tradisonal. Pada perancangan buku pop-up alat transportasi tradisional Palembang akan menggunakan beberapa alat transportasi tradisional Palembang dan alat transportasi tradisional lainnya, yaitu untuk alat transportasi tradisional Palembang adalah becak khas Palembang dan perahu ketek. Alat transportasi tradisional lainnya adalah delman dan sepeda onthel.

\section{Media Pendukung \\ a. Poster}

poster sebagai media promosi yang ditargetkan pada orang tua dari anak usia 3-5 tahun. Ukuran poster yang akan digunakan adalah $42 \mathrm{~cm}$ x 59,4 cm dan 59,4 cm x $84,1 \mathrm{~cm}$ yang akan ditampilkan di toko buku dan Tk serta Paud yang berada di Kota Palembang.

\section{b. X- Banner}

$\mathrm{X}$ banner merupakan salah media promosi yang akan digunakan pada buku pop-up alat transportasi tradisional Palembang dengan ukuran $60 \mathrm{~cm}$ x $160 \mathrm{~cm}$. Pada x banner akan menampilkan judul buku, gambar dari tokoh utama dan produk buku pop-up itu sendiri yang diharapkan orang tua dari anak usia 3-5 tahun maupun masyarakat 
yang membutuhkannya akan tertarik untuk membeli buku pop-up alat transportasi tradisional Palembang ini sebagai media edukasi.

\section{c. Stiker}

Stiker pada buku pop-up alat transportasi tradisional Palembang berukuran $8,5 \mathrm{~cm}$ x $9 \mathrm{~cm}$ digunakan sebagai media promosi berupa bonus yang akan didapatkan pada setiap pembelian buku pop-up alat transportasi tradisional Palembang. Stiker pada buku pop-up alat transportasi tradisional Palembang terdapat 5 buah dengan masingmasing dari bentuk dan nama alat transportasi, yang diharapkan orang tua dari anak usia 3-5 tahun akan tertarik untuk membelikan buku pop-up alat transportasi tradisional Palembang.

\section{d. Gantungan kunci dan pin}

Gantungan Kunci dan Pin sebagai merchandise dan sebagai bonus dalam pembelian buku pop-up alat transportasi tradisional Palembang. Gantungan Kunci dan Pin terdiri dari bentuk alat transportasi tradisional dan nama alat transportasi tradisional tersebut, dengan ukuran gantungan kunci dan pin $5 \mathrm{~cm}$.

\section{e. Kaos}

Kaos dijadikan sebagai merchandise pada saat pameran. Pada kos terdapat gambar alat-alat transportasi tradisional Palembang, serta tokoh utama pada buku popup ini yaitu Lila dan Lilo, selain itu juga akan ada pemandangan jembatan ampera sebagai background.

\section{f. Rak Buku}

Rak buku akan digunakan sebagai tempat menyimpan buku pop-up alat transportasi tradisional Palembang pada saat pameran ataupun disimpan di toko buku. Rak buku yang terbuat dari kayu dengan ukuran panjang $85 \mathrm{~cm}$ dan lebar $60 \mathrm{~cm}$ terdiri dari judul buku pada masing-masing sisi rak buku dan terdapat alat transportasi tradisional Palembang.

Pada perancangan buku pop-up alat transportasi tradisional ini dibutuhkan sketsa ataupun layout yang akan dipilih dan dipakai pada perancangan buku pop-up ini. Pada tahap pertama di perlukannya pembuatan sketsa kasar baik untuk headline, cover, dan ilustrasi cerita. Berikut adalah sketsa kasar yang sudah di rancang :

\section{a. Headline}

Headline merupakan judul utama yang akan digunakan pada buku pop-up alat transportasi tradisional Palembang. Pada headline akan menggunakan kalimat yang bersifat mengajak dan mdapat menarik perahtian. Berikut sketsa kasar pada bagian headline.

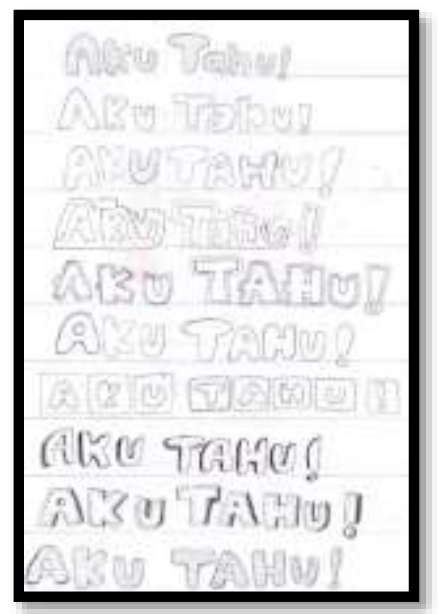

Gambar 2. Headline buku 1

Pada gambar 2 terdapat beberapa pilihan sketsa headline buku ke 1 yang sudah dirancang. Dan selanjutnya sketsa yang sudah dibuat akan di pilih salah satu.

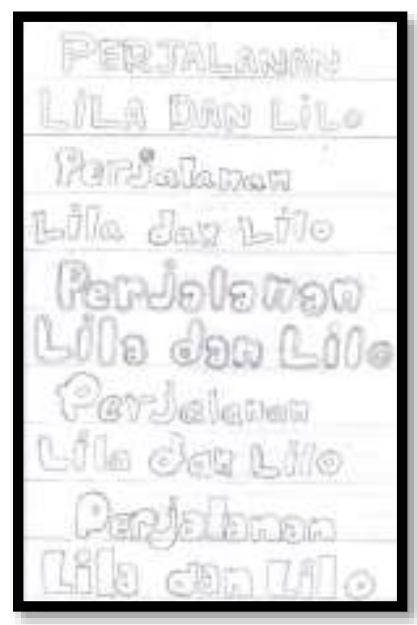

Gambar 3. Headline buku 2

Pada gambar 3 terdapat beberapa pilihan sketsa headline untuk buku ke 2 yang sudah dirancang. Dan selanjutnya sketsa yang sudah dibuat akan di pilih salah satu.

\section{b. Cover}

Buku 1:

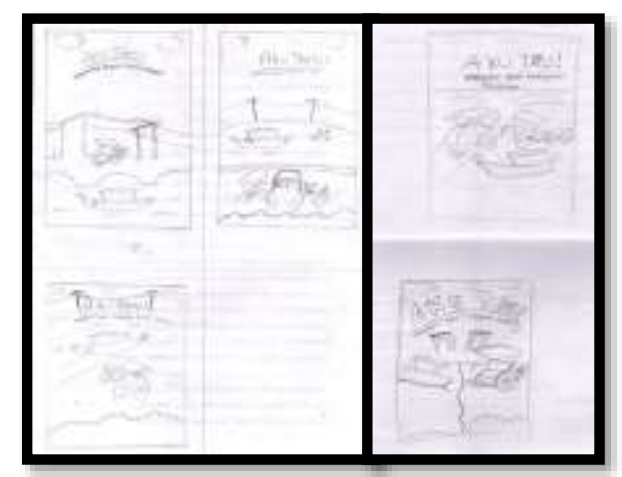




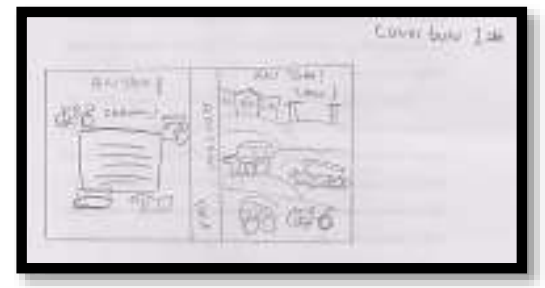

Gambar 4. Sketsa cover Buku 1

Pembahasan pada gambar 4 merupakan sketsa untuk cover buku 1 yang dibuat beberapa desain dan akan dipilih salah satu. Disetiap sketsa cover terdapat bentukbentuk dari alat transportasi tradisional Palembang dan juga jembatan ampere yang merupakan ciri khas dari kota Palembang.

\section{Buku 2}
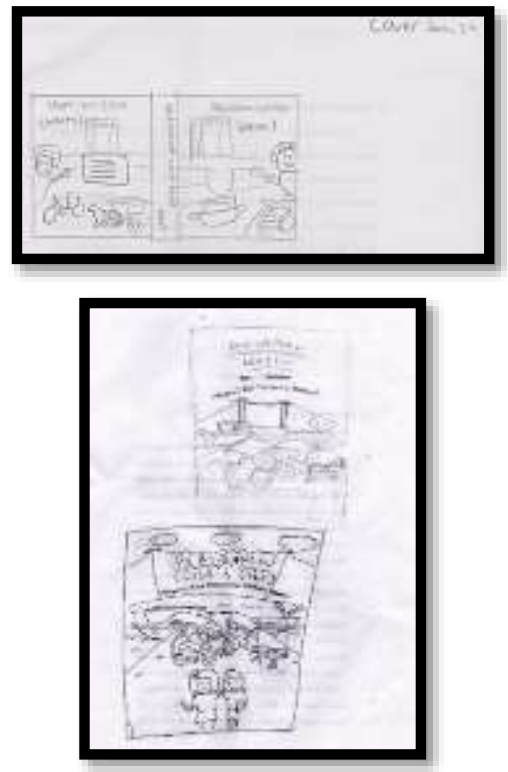

Gambar 5. Sketsa cover buku 2

Pembahasan pada gambar 5 merupakan sketsa untuk cover buku 2 yang dibuat beberapa desain dan akan dipilih salah satu. Desain setiap sketsa cover menggunakan bentuk- bentuk alat transportasi tradisional palembang, namun di buku 2 ditambahkan 2 tokoh utama pada buku pop-up ini.

\section{c. Ilustrasi Cerita}

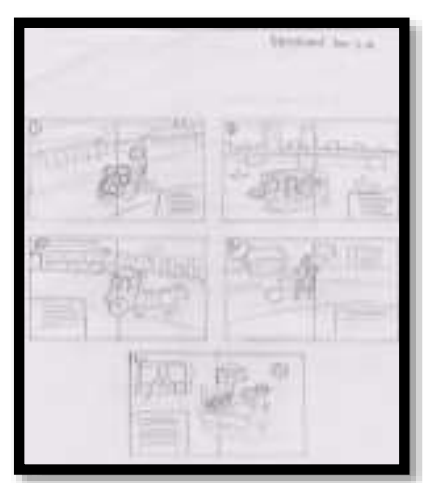

Gambar 6. Story board cerita buku 1
Pembahasan gambar 6, Pada seketsa ilustrasi cerita buku 1 digambarkan setiap halaman terdapat alat trasnportasi tradisional Palembang yang akan menjadi pusat perhatian karena akan dibuat dengan tekhnik pop-up dan akan dijelaskan dari tiap-tiap alat transportasi.

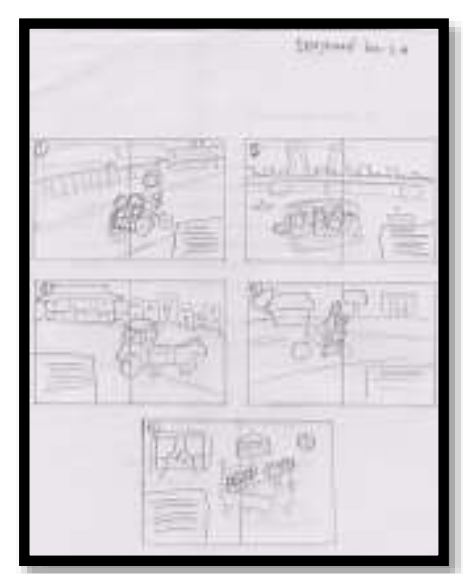

Gambar 7. Story board cerita buku 2

Pembahasan gambar 7, Pada seketsa ilustrasi cerita buku 2 digambarkan setiap halaman terdapat alat trasnportasi tradisional Palembang dan 2 tokoh utama yang akan menjadi pusat perhatian karena akan dibuat dengan tekhnik pop-up dengan mengunakan alur cerita.

Setelah melalui proses pembuatan sketsa, maka dipilihlah salah satu desain yang dioleh secara digital. Berikut merupakan sketsa alternatif yang sudah dipilih dan telah di olah digital:

\section{a. Headline}

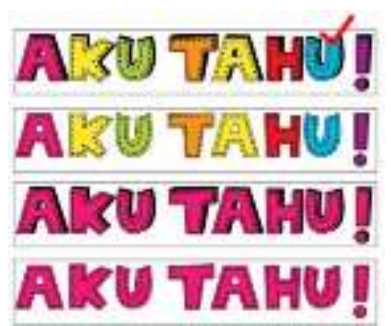

Gambar 8. Alternatif Headline Buku 1

Pembahasan gambar 8 adalah Dipilihnya desain yang pertama untuk judul buku ke 1 karena warna dan bentuk sesuai dengan buku untuk anak-anak yang menyukai warna-warna cerah dengan garis yang tebal.

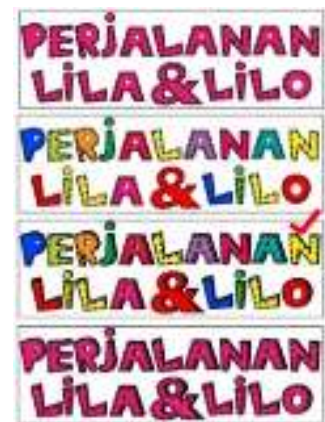

Gambar 9. Alternatif Headline Buku 2 
Pembahasan gambar 9 adalah Dipilihnya desain yang ketiga untuk judul buku ke 2 karena warna dan bentuk sesuai dengan buku untuk anak-anak yang menyukai warna-warna cerah dengan garis yang tebal.

\section{b. Cover}
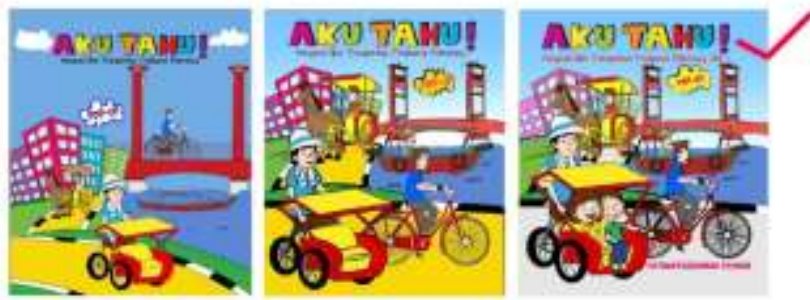

Gambar 10. Alternatif Cover Buku 1

Pembahasan gambar 10 dipilihnya gambar ke 3 karena perpaduan warna, dan bentuk gambar sesuai dengan psikologi anak-anak usia 3-5 tahun.
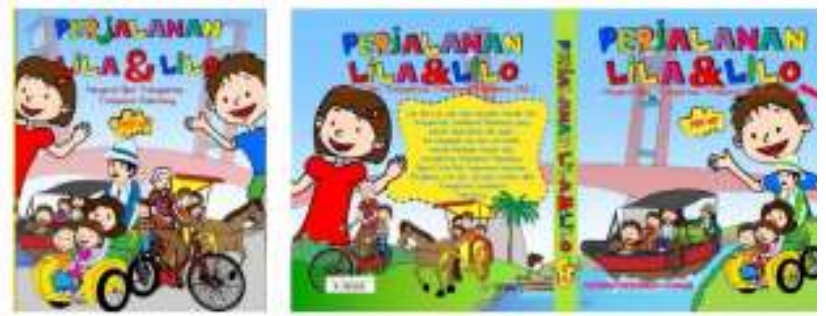

Gambar 11. Alternatif Cover Buku 2

Pembahasan gambar 11 dipilihnya gambar ke 2 karena gambar ke 2 memiliki keunikan dengan cover yang menjadi alur cerita di bagian depan sampai ke bagian belakang, dengan memasukan dua tokoh utama serta alt trasnportasi tradisional Palembang serta jembatan ampere sebagai ciri kota palembang.

Setelah melalui proses pemilihan sketsa digital maka dipilihlah satu sketsa yang akan digunakan pada perancangan buku pop-up alat transportasi tradisional Palembang. Berikut deain yang sudah dipilih dan akan dipakai pada perancangan ini :

\section{a. Headline}

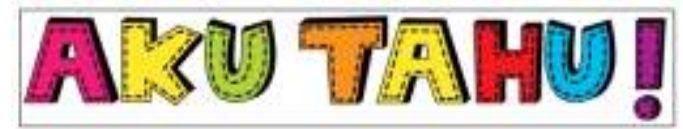

Gambar 12. Headline Buku 1

Pembahasan gambar 11 yaitu dengan judul "Aku Tahu" yang bermaksud bahwa setelah anak-anak membaca buku ini maka mereka anak mengetahui alat transportasi tradisional Palembang, baik dari bentuk dan cara penggunaan melalui buku pop-up ini..

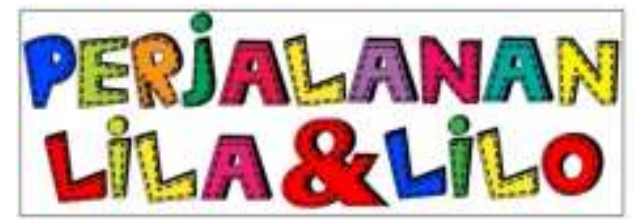

Gambar 13. Headline Buku 2
Pembahasan gambar 12 yaitu dengan judul "Perjalanan Lila \& Lilo" yang bermaksud bahawa pada buku ini akan di ceritakan begitu menyenagkannya perjalanan lila dan lilo dengan menggunakan alat trasnportasi tradisional Palembang.

\section{b. Cover Buku}

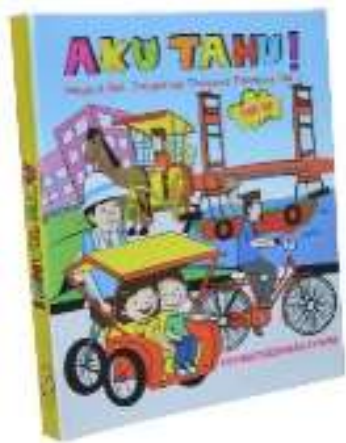

\section{Gambar 14. Cover Buku 1}

Pambahasan gambar 14 merupakan hasil cetak dari cover buku ke 1 dengan judul "AKu Tahu" dengan menggunakan cover yang sudah dipilih sebelumnya.

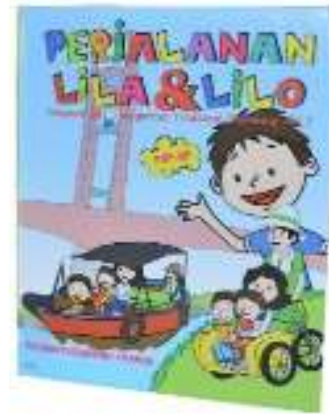

\section{Gambar 15. Cover Buku 2}

Pembahasan gambar 15 yang merupakan hasil cetak cover buku ke 2 yang berjudul "Perjalanan Lila\&Lilo" dengan menggunakan cover yang sudah dipilih sebelumnya.

\section{c. Poster}

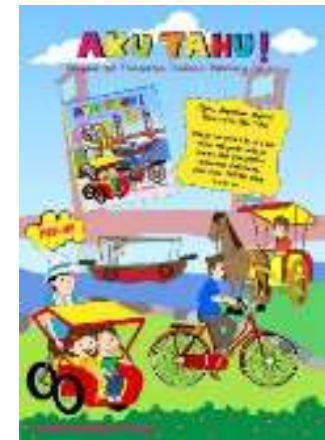

Gambar 16. Poster ukuran $59,4 \mathrm{~cm} \times 84,1 \mathrm{~cm}$

Pembahasan gambar 16 merupakan poster yang merupakan media pendukung dari buku pop-up ini dengan ukura A1 dengan maksud untuk mempromosikan 
buku pop-up alat transportasi tradisional Palembang ini dengan menggunakan headline "Aku Tahu"

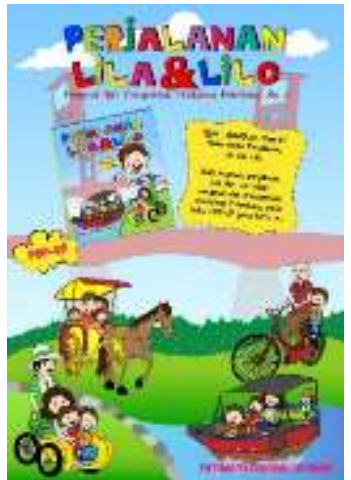

Gambar 17. Poster ukuran $59,4 \mathrm{~cm} \times 84,1 \mathrm{~cm}$

Pembahasan gambar 17 merupakan poster untuk mempromosikan buku ke 2 dengan headline "Perjalanan Lila\& Lilo"

\section{d. X- Banner}
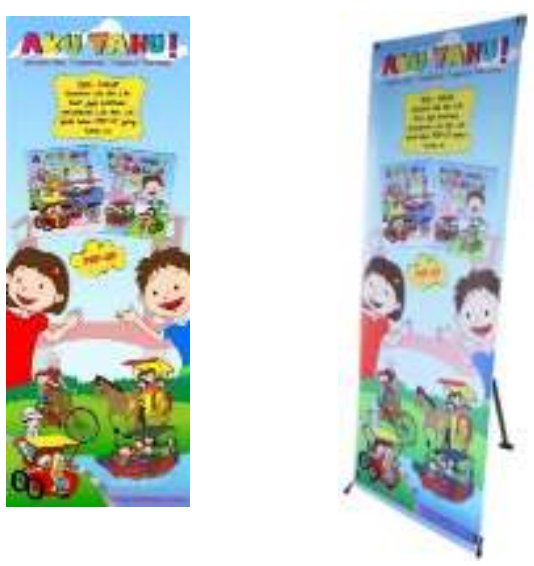

Gambar 18. X-Banner

Pembahasan gambar $18 \mathrm{x}$ banner digunakan untuk mempromosikan buku pop-up ini dengan memasukan gambar ke dua huku dan tokoh utama serta alat transportasi tradisionalnya.

\section{e. Stiker}

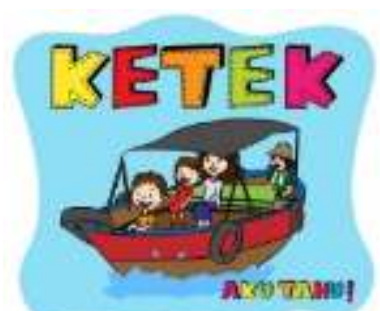

Gambar 19. Stiker Perahu Ketek

Pembahasan gambar 19 merupakan salah satu stiker alat transportasi tradisional Palembang, yaitu perahu Ketek, yang berfungsi sebagai media promosi yang akan didapat setiap pembelian buku pop-up ini.

\section{f. Gantungan Kunci}

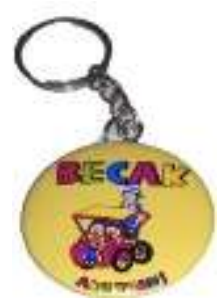

Gambar 20. Gantungan Kunci Becak

Pembahasan gambar 20 merupakan salah satu gantungan kunci yang yang bergambar becak. Gantungan kunci ini merupakan merchandise disetiap pembelian buku pop-up.

\section{g. Pin}

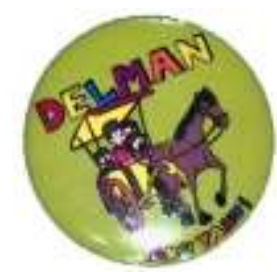

Gambar 21 Pin Delman

Pembahasan gambar 21 adalah salah satu pin dengan gambar delman. Pin ini merupakan merchandise disetiap pembelian buku pop-up ini.

\section{h. Kaos}

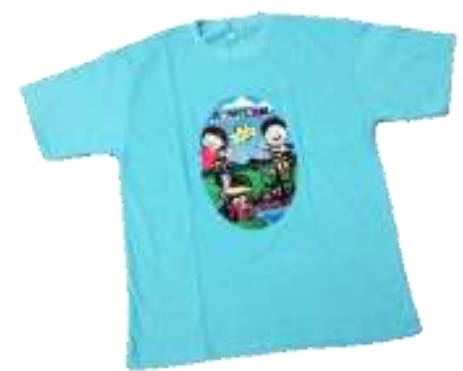

Gambar 22. Kaos " $A K U T A H U$ ”

Pembahasan gambar 22 adalah kaos yang merupakan media promosi pada perancangan buku pop-up alat transportasi tradisional Palembang.

\section{i. Rak Buku}

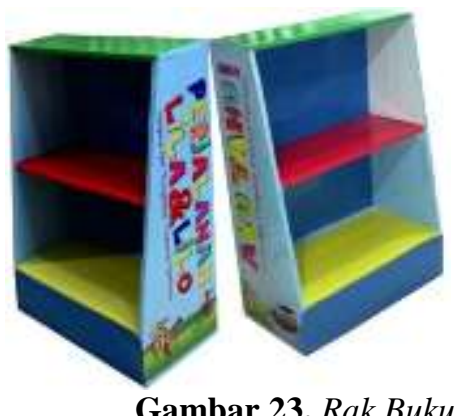

Gambar 23. Rak Buku 
Pembahasan gambar 23 yaitu rak buku sebagai media promosi yang akan digunakan di setiap toko buku.

\section{Kesimpulan}

Buku pop-up dapat dijadikan salah satu pilihan media edukasi yang tepat untuk anak usia 3-5 tahun, karena buku pop-up memberikan visualisasi cerita yang lebih dominan sehingga dapat melatih proses perkembangan kreatifitas dan imajinasi anak. Buku pop-up untuk anak-anak usia 35 tahun yang berada di pasaran didominasi oleh ceritacerita imaginatif seperti cerita princces, Disney dan cerita transportasi modern seperti pesawat dan kereta api yang merupakan alat transportasit moderen. Hal ini menyebabkan banyak anak-anak kurang mengenal alat transportasi tradisional dan orang tua yang melupakan alat transportasi tradisional.

Perkembangan zaman dan teknologi membuat masyarakat lupa akan nilai tradisi dan budaya, salah satunya adalah alat transportasi tradisional yang saat ini sudah mulai tergantikan dengan alat transportasi modern. Kota Palembang merupakan salah satu kota yang memiliki alat transportasi tradisional yang khas, yaitu perahu "ketek" dan becak yang saat ini sudah mulai terlupakan dan tergantikan oleh alat transportasi modern, oleh karena permasalahan tersebut maka diangkatlah ide perancangan pada perancangan buku pop-up ini adalah "Perancangan Buku Pop-up Alat Transportasi Tradsioanl Palembang".

Melalui perancangan buku pop-up alat transportasi tradisional Palembang dapat memberi kesempatan anakanak usia 3- 5 tahun menggunakan nalar dan mengungkapkan pikirannya dengan menggunakan kosa kata yang semakin hari semakin bertambah, serta menambah perkembangan pada segi visual, karena strategi mengingat yang sangat cerdas dan penting adalah visualisasi, selain dari itu perancangan buku pop-up alat transportasi tradisional Palembang dapat menambah ilmu pengetahuan bagi anak-anak usia 3- 5 tahun, dan dapat meningkatkan nilai-nilai tradisi dan budaya lokal yang saat ini sudah mulai terlupakan oleh pemerintah dan masyarakat dengan memperkenalkan alat transportasi tradisional Palembang.

\section{Saran}

Bagi penulis, diharapkan dapat lebih kreatif dan berinovasi dalam menghasilkan sebuah karya buku popup atau karya lainnya dengan mengangkat cerita atau tradisi masyarakat nusantara sebagai tema atau ide perancangan.

Bagi mahasiswa Desain Komunikasi Visual UIGM Palembang, diharapkan dengan membaca laporan dan menyaksiskan pameran dapat menjadi sumber inspirasi, dan sumber ilmu agar nantinya dapat lebih kreatif dalam berkarya. Sehingga dapat berinovasi dalam menciptakan karya desain baru yang lebih menarik dan berkualitas tinggi.

Bagi Orang Tua dan anak, dapat mengambil nilai-nilai budaya dan tradisi yang terkandung dalam buku pop up ini yang sudah mulai dilupakan oleh masyarakat, salah satunya dengan tetap menggunakan alat transportasi tradisional, agar tetap lestari. Buku pop-up ini juga diharapkan dapat dijadikan media edukasi untuk anak usia 3-5 tahun serta dapat menumbuhkan minat baca pada anak dengan disajikannya ilutrasi yang menarik. Sehingga dapat menambah ilmu pengetahuan untuk anak usia 3-5 tahun di perisode emasnya.

\section{Daftar Pustaka}

[1] Asfandiyar, Andi Yudha "Cara Pintar Mendongeng," Dar! Mizan, Bandung, 2007.

[2] Tuttle, Cherly Greson dan Peny Hutchibis paquette "Thinking Game for Kids", Andi, Yogyakarta. 2008.

[3] Sugiyono, " Metode Penelitian kuantitatif kualitatif dqan R\& D”, Alfabeta, Bandung, 2010

[4] Rustan, Surianto, "Mendesain LOGO", PT. Gramedia Pustaka Utama, Jakarta. 2009.

[5] Kustrianto, Adi, "Pengatar Desain Komunikasi Visual", Andi, Yogyakarta, 2009

[6] Sefrina, Andi, "Deteksi Minat Bakat Anak", Media Perindo, Yogyakarta, 2013 